\title{
Sphenopalatine ganglion block for post-dural puncture headache after invasive cerebrospinal fluid pressure monitoring. Case report
}

\author{
Bloqueio esfenopalatino para cefaleia pós-punção dural causada por monitorização invasiva de \\ pressão liquórica. Relato de caso
}

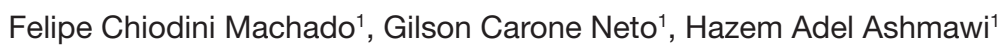

DOI 10.5935/2595-0118.20190072

\section{ABSTRACT}

BACKGROUND AND OBJECTIVES: Post-dural puncture headache is a common complication in neuraxial anesthesia and lumbar puncture diagnostic procedures. The pathogenesis of the headache is thought to be due to a leak of cerebrospinal fluid from the puncture site that exceeds the rate of cerebrospinal fluid production, causing a downward traction of the meninges and vasodilation of the meningeal vessels mediated by the autonomous nervous system. Nowadays, the conservative treatment involves hydration, and the use of caffeine, analgesics, hydrocortisone, gabapentin, and theophylline. However, an autologous epidural blood patch is considered the definitive treatment for post-dural puncture headache and has an efficacy of up to $75 \%$. Since this procedure comes with intrinsic risks, an alternative is the sphenopalatine ganglion block.

CASE REPORT: We describe a case report using a sphenopalatine ganglion block to treat post-dural puncture headache in a patient submitted to cerebrospinal fluid pressure monitoring with a subarachnoidal catheter inserted with a low-gauge needle. CONCLUSION: This is the first case report of a post-dural puncture headache caused by a subarachnoid monitoring catheter successfully treated with sphenopalatine ganglion block. This technique can be a non-invasive option in the management of post-dural puncture headache, which requires more study to evaluate its efficacy and safety.

Keywords: Headache, Post-dural puncture headache, Sphenopalatine ganglion block.

Felipe Chiodini Machado - (Dhttps://orcid.org/0000-0003-1615-2597;

Gilson Carone Neto - Dhttps://orcid.org/0000-0001-8604-8985;

Hazem Adel Ashmawi - Dhttps://orcid.org/0000-0003-0957-971X.

1. Universidade de São Paulo, Faculdade de Medicina, Hospital das Clínicas, Disciplina de Anestesiologia. São Paulo, SP, Brasil.

Submitted on May 02, 2019.

Accepted for publication on September 27, 2019.

Conflict of interests: none - Sponsoring sources: none.

Correspondence to:

Rua Oscar Freire, 1929/404

05409-011 São Paulo, SP, Brasil.

E-mail: felipe.chiodini@hotmail.com

(C) Sociedade Brasileira para o Estudo da Dor

\section{RESUMO}

JUSTIFICATIVA E OBJETIVOS: A cefaleia pós-punção pontual é uma complicação comum nos procedimentos de anestesia neuroaxial e punção lombar diagnóstica. Acredita-se que a patogênese da cefaleia seja devida a um vazamento de líquido cefalorraquidiano do local da punção que excede a taxa de produção de líquido cefalorraquidiano, causando uma traçáo descendente das meninges e vasodilataçấo dos vasos meníngeos mediada pelo sistema nervoso autônomo. Atualmente, o tratamento conservador envolve a hidratação e o uso de cafeína, analgésicos, hidrocortisona, gabapentina, teofilina, porém, o tampão sanguíneo peridural autólogo é considerado o tratamento definitivo para a cefaleia pós-punção pontual e tem eficácia de até $75 \%$. Dado que esse procedimento vem com riscos intrínsecos, uma alternativa é o bloqueio ganglionar esfenopalatino.

RELATO DO CASO: O estudo relata um caso utilizando com sucesso o bloqueio ganglionar esfenopalatino para tratar cefaleia pós-punção dural em um paciente submetido à monitorização da pressão liquórica com um cateter subaracnoideo inserido com uma agulha de pequeno calibre.

CONCLUSĀO: Este é o primeiro relato de caso de cefaleia pós-punçáo dural causada por um cateter subaracnoideo de monitorização de pressão liquórica e tratada com sucesso com o uso de bloqueio de gânglio esfenopalatino. Esta técnica pode ser uma das opçôes náo invasivas no manuseio da cefaleia por hipotensão liquórica e requer maior estudo para avaliar sua eficácia e segurança. Descritores: Bloqueio do gânglio esfenopalatino, Cefaleia, Cefaleia pós-punção dural.

\section{INTRODUCTION}

Post-dural puncture headache (PDPH) is a common complication in neuraxial anesthesia and lumbar puncture diagnostic procedures. The incidence of PDPH is inversely proportional to the gauge of the needle which punctures the dura, thus in anesthesia it is more common for the patient to experience PDPH after accidental dural puncture with 16-gauge Tuohy needle (70\% chance of PDPH) than after dural puncture with 29-gauge Quincke needle (less than $2 \%)^{1}$. The pathogenesis of the headache is thought to be due to a leak of cerebrospinal fluid from the puncture site that exceeds the rate of cerebrospinal fluid production, causing a downward traction of the meninges and vasodilation of the meningeal vessels mediated by the autonomous nervous system ${ }^{1}$. 
Nowadays, the conservative treatment involves hydration and the use of caffeine, analgesics, hydrocortisone, gabapentin, theophylline ${ }^{2}$. Nevertheless, such treatment is not always effective, and an interventional technique is applied. Autologous epidural blood patch (AEBP) is considered the definitive treatment for PDPH and has an efficacy of up to $75 \% \%^{1,3}$. However, this procedure comes with intrinsic risks, such as difficulty in identifying the epidural space, a new accidental dural puncture, patient discomfort during the procedure, infection, hemorrhagic and neurologic complications $s^{4}$.

An alternative between conservative treatment and the AEBP is the sphenopalatine ganglion block (SPGB). The sphenopalatine ganglion is a neural structure located in the pterygopalatine fossa and has both a sympathetic and a parasympathetic component of the autonomous system, as well as somatic sensory roots. It can be accessed through transcutaneous or transnasal approaches. The SPGB has been successfully used in pain clinic practice to treat chronic headaches, atypical facial pain, and even trigeminal neuralgia ${ }^{5,6}$. The transnasal approach ${ }^{7}$ is a noninvasive technique that can be easily performed and could be beneficial to PDPH by blocking the parasympathetic tonus at the cerebral vasculature, returning them to their normal diameter and relieving the headache with a low cost and low risks procedure ${ }^{8}$. The related complications reported with the transnasal technique are minor bleeding and temporary nasal discomfort.

There are no clinical trials on this hypothesis; only two recent case reports showed the use of SPGB to treat PDPH in patients who underwent diagnostic lumbar puncture in the emergency room $^{7}$ or obstetric anesthesia ${ }^{9}$. Both case reports have shown positive results, eventually avoiding the necessity of AEBP in refractory patients to conservative treatments.

We describe a case report using SPGB to treat PDPH in a patient submitted to cerebrospinal fluid pressure monitoring with a subarachnoidal catheter inserted with a low-gauge needle.

\section{CASE REPORT}

The patient was a 45 -year-old man, $85 \mathrm{~kg}, 165 \mathrm{~cm}$, with a history of systemic arterial hypertension and hypercholesterolemia who underwent open thoracic surgery for aorta aneurysm correction with cerebrospinal fluid pressure monitoring.

Upon the subarachnoid catheter withdraw, the patient developed PDPH, which was evaluated with the visual numeric scale (VNS), varying from zero to 10 . He rated the intensity as 8 while sitting or standing, and zero while lying down. The surgical team initiated the conservative treatment with caffeine, analgesics, and hydration, but it was not effective after 12 hours.

We have confirmed the clinical diagnosis of PDPH, and we offered an SPGB as a non-invasive option to relieve the pain. The patient was also offered an AEBP and informed that the latter was the current definitive therapy.

After agreeing on the SPGB, the block was performed with the patient in the supine position, with the neck flexed and the head extended. Gauzes soaked in $15 \mathrm{~g}$ of a $2 \%$ lidocaine gel were inserted carefully into each nostril until it reached the nasopharynx posterior wall. They were left in place for 10 minutes and removed (Figure 1).

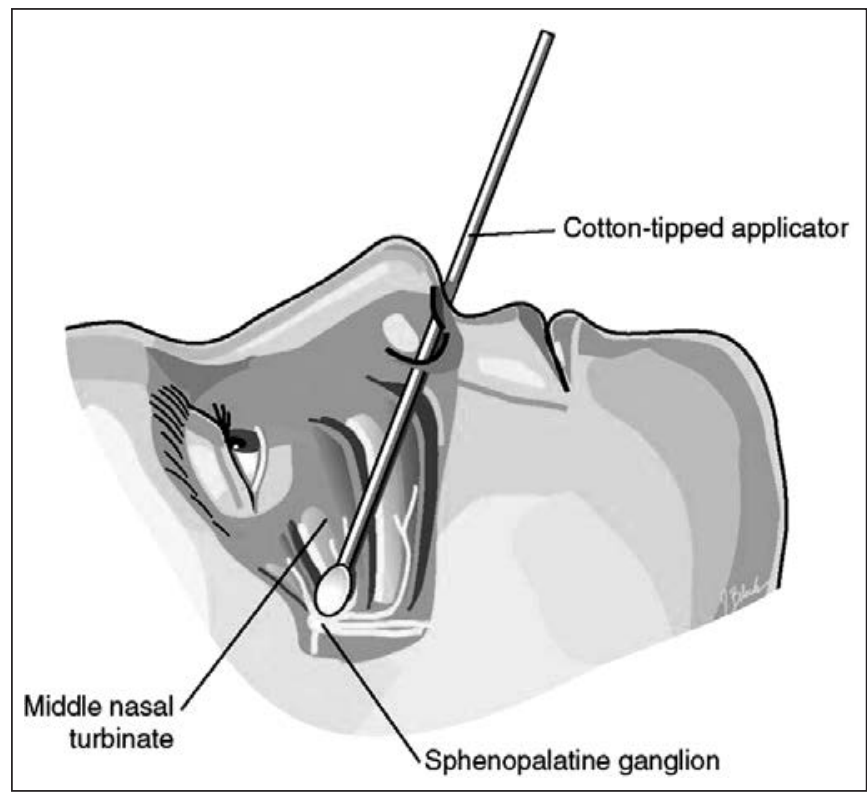

Figure 1. Sphenopalatine ganglion block

After removal, the patient had no pain while sitting or walking (visual analog scale (VAS) score of zero/10). There was a minor discomfort during the gauze insertion, but no bleeding occurred. The previous clinical treatment was maintained, associated with gabapentin $(600 \mathrm{mg})$ per day was. The pain returned after 12 hours, but with the intensity of 3 using the VAS score and was considered mild and tolerable for about 5 hours sitting and walking. During this period, the patient refused AEBP, given the mildness of the pain and only the clinical treatment was maintained. After $5 \mathrm{~h}$, the patient was pain-free again. At $24 \mathrm{~h}$ and $48 \mathrm{~h}$ post block the patient had no pain. The treatment was suspended after $48 \mathrm{~h}$, and the patient was discharged. By a phone contact five days later, there were no reports of headache recurrence (Table 1$)$.

Table 1. Relevant data from this episode of care organized as a timeline

\begin{tabular}{ll}
\hline Days & \\
\hline 1 & $\begin{array}{l}\text { Patient submitted to a thoracic surgery for aorta aneurysm } \\
\text { correction }\end{array}$ \\
3 & $\begin{array}{l}\text { Catheter withdrawal and PDPH symptoms and beginning } \\
\text { of conservative treatment }\end{array}$ \\
3 & Pain Team evaluation and treatment \\
4 & Evaluation 24 hours after the procedure \\
5 & Evaluation 48 hours after the procedure and discharge \\
10 & Evaluation 7 days after the procedure
\end{tabular}

$\mathrm{PDPH}=$ post-dural puncture headache.

\section{DISCUSSION}

This is the first case-report of PDPH caused by an invasive monitoring anesthetic method, which was refractory to clinical treatment and solved with SPGB without the need for AEBP.

The supratentorial dura mater membrane is supplied by small meningeal branches of the trigeminal nerve (V1, V2, and V3). 
The innervation for the infratentorial dura mater is via upper cervical nerves. The second division of the trigeminal nerve (V2) runs through the sphenopalatine ganglion (SPG), which is anatomically accessible to blocking due to its superficial location in the nasal cavity ${ }^{10}$. The proposed mechanism is that with the SPGB, the parasympathetic tonus of the cerebral vasculature is reduced, allowing the dilated blood vessels to return to the normal diameter, reducing intracranial volume and thus alleviating PDPH symptoms. In a recent observational study, it was evidenced that there were temperature changes in both sides of the V1 area, which corroborates the theory that there is reduction of meningeal blood flow ${ }^{11}$.

We used $2 \%$ viscous lidocaine because that is what was available at our institution. Although other studies had used 4-5\% lidocaine, we had similar results with a lower concentration of lidocaine $^{12}$. In this case, the patient had complete pain resolution for $12 \mathrm{~h}$, a mild pain relapse for $5 \mathrm{~h}$ and no pain in later evaluations. The analgesic treatment was maintained for the first two days after the block, which might have contributed to the prolongation of the analgesic effect. Another possibility is that once the parasympathetic tonus is reduced with the blockade, it does not increase again.

The SPGB can be performed in ambulatory patients. Non-specialized medical staff, surgical staff, and even the patient himself can use this simple technique, as it is already used for orofacial pain, headaches, and trigeminal neuralgia ${ }^{13,14}$. Despite being a simple technique, SPGB requires training to increase its efficacy and reduce potential complications ${ }^{14}$. This technique needs further clinical trials using different anesthetics, dosages and compared to conservative treatments, and the results achieved in this case report, and others are concordant and encouraging ${ }^{15}$. If used in a clinically refractory patient, SPGB has the potential to relieve PDPH rapidly and may prevent the use of an invasive treatment ${ }^{16}$. The risks of a transnasal SPGB are mainly bleeding, and temporary discomfort ${ }^{6}$ are significantly lower than the risks of the AEBP, which includes dural puncture, neurologic complications, bleeding, and infection ${ }^{17,18}$.
This is the first case report of a PDPH caused by a subarachnoid monitoring catheter successfully treated with SPGB. This technique can be a non-invasive option in the management of PDPH, which requires more study to evaluate its efficacy and safety.

\section{REFERENCES}

1. Turnbull DK, Shepherd DB. Post-dural puncture headache: pathogenesis, prevention and treatment. Br J Anaesth. 2003;91(5):718-29.

2. Basurto Ona X, Osorio D, Bonfill Cosp X. Drug therapy for treating post-dural puncture headache. Cochrane Database Sys Rev. 2015;15(7):CD007887.

3. Safa-Tisseront V, Thormann F, Malassiné P, Henry M, Riou B, Coriat P, et al. Effectiveness of epidural blood patch in the management of post-dural puncture headache. Anesthesiology. 2001;95(2):334-9

4. Paech M. Epidural blood patch-myths and legends. Can J Anesth. 2005;(52):R1-5.

5. Day M. Sphenopalatine ganglion analgesia. Curr Rev Pain. 1999;3(5):342-7.

6. Slullitel A, Santos IS, Machado FC, Sousa AM. Transnasal sphenopalatine nerve block for patients with headaches. J Clin Anesth. 2018;47:80-1.

7. Kent S, Mehaffey G. Transnasal sphenopalatine ganglion block for the treatment of postdural puncture headache in the ED. Am J Emerg Med. 2015;33(11):1714.e1-2.

8. Edvinsson L. Innervation and effects of dilatory neuropeptides on cerebral vessels. New aspects. Blood Vessels. 1991;28(1-3):35-45.

9. Kent $S$, Mehaffey G. Transnasal sphenopalatine ganglion block for the treatment of postdural puncture headache in obstetric patients. J Clin Anesth. 2016;34:194-6.

10. Lima MH, Campos MJ, Valentim A, Paulo L, Rego S, Semedo E. Intranasal self-administration of local anesthetic (ropivacaine) for sphenopalatine ganglion block, for treatment of second trigeminal branch neuralgia secondary to maxillary sinus curettage: a case report. Rev Esp Anestesiol Reanim. 2019;5. pii: S0034-9356(19)30067-2. [Epub ahead of print].

11. Kim NE, Park B, Moon YR, Lee SY, Gil HY, Kim S, et al. Changes in facial temperature measured by digital infrared thermal imaging in patients after transnasal sphenopalatine ganglion block: retrospective observational study. Medicine (Baltimore). 2019;98(15):e15084. doi: 10.1097/MD.0000000000015084.

12. Peterson JN, Schames J, Schames M, King E. Sphenopalatine ganglion block: a safe and easy method for the management of orofacial pain. Cranio. 1995;13(3):177-81.

13. Furtado IF, Pinto MM, Amorim P. Sphenopalatine ganglion block may be an efficient treatment of headache after lumboperitoneal shunt placement: a case report. A A Pract. 2019;12(11):401-2.

14. Davies JM, Murphy A, Smith M, O'Sullivan G. Subdural haematoma after dural puncture headache treated by epidural blood patch. Br J Anaesth. 2001;86(5):720-3.

15. Stalis C, Zatochill M, Petersen TR, Falcon RJ, Al Haddadin C, Southwell B, et al. Transnasal sphenopalatine ganglion block for postdural puncture headache in an adolescent: a case report. A A Pract. 2019;30 [Epub ahead of print].

16. Jespersen MS, Jaeger PT, Aegidius KL, Meyhoff CS. [Sphenopalatine ganglion block for treatment of post-dural puncture headache]. Ugeskr Laeger. 2019;181(19). pii: V12180846. Danish.

17. Mehta SP, Keogh BP, Lam AM. An epidural blood patch causing acute neurologic dysfunction necessitating a decompressive laminectomy. Reg Anesth Pain Med. 2014;39(1):78-80.

18. Tekkök IH, Carter DA, Brinker R. Spinal subdural haematoma as a complication of immediate epidural blood patch. Can J Anaesth. 1996;43(3):306-9. 